\title{
GIBBERELLIC ACID REDUCES FLOWERING AND TIME OF MANUAL THINNING IN 'MACIEL' PEACH TREES'
}

\author{
MARCOS ANTÔNIO GIOVANAZ², JOSÉ CARLOS FACHINELLO ${ }^{3}$, \\ DANIEL SPAGNOL ${ }^{2}$, DIEGO WEBER ${ }^{2}$, BRUNO CARRA²
}

\begin{abstract}
The thinning peach fruits is to reduce the load of the plant with the aim to improve the size, flavor and color of the remaining fruits. However, the practice of thinning requires high demand of manpower and become more expensive the production costs. The objective of this study was to evaluate the reduction of flowering buds and the time of hand thinning in 'Maciel' peach after gibberellic acid $\left(\mathrm{GA}_{3}\right)$ application at different times and concentrations. The experiments were performed in the harvests of 2012 and 2013 in a commercial peach orchard located in the county of Morro Redondo, RS. The plants of cultivar Maciel, in 2012, were sprayed with four doses of $\mathrm{GA}_{3} 0,25,75$ and $125 \mathrm{mg} \mathrm{L}^{-1}$, at different times 20, 40 and 60 days after full bloom (DAFB). The number of flowering buds and consequently the number of flowers was reduced in the 2013 season after application of $\mathrm{GA}_{3}$ on the 2012 harvest. The manual thinning decreased with doses applied at 60 DAFB. The number of flowering buds and consequently the number of flowers was reduced in 2013. There was reduction of manual thinning when applied at 60 DAFB. The doses of 25, 75 and 125 $\mathrm{mg} \mathrm{L}^{-1}$ applied at $60 \mathrm{DAFB}$ resulted in a reduction of 50.1, 76.9 and $87.1 \%$, respectively, at the time of hand thinning. When applied the dose of $25 \mathrm{mg} \mathrm{L}^{-1}$ of GA at 60 DAFB reduces the number of flowering buds and hand thinning time in the next cycle in 'Maciel' peach, without compromising production.
\end{abstract}

Index terms: Peach, gibberellin, return bloom, inhibition of flowers, manpower, stone fruit trees.

\section{ÁCIDO GIBERÉLICO REDUZ O FLORESCIMENTO E O TEMPO DE RALEIO MANUAL EM PESSEGUEIRO 'MACIEL'}

\begin{abstract}
RESUMO- O raleio de frutos em pessegueiro visa a reduzir a carga da planta com o objetivo de melhorar o tamanho, o sabor e a coloração dos frutos remanescentes. No entanto, a prática do raleio exige alta demanda de mão de obra, encarecendo os custos de produção. O objetivo deste trabalho foi avaliar a redução de gemas floríferas e o tempo de raleio manual em pessegueiro 'Maciel' após a aplicação de ácido giberélico $\left(\mathrm{AG}_{3}\right)$, em diferentes épocas e concentrações. O experimento foi realizado nas safras de 2012 e 2013, em pomar comercial de pessegueiro localizado no município do Morro Redondo-RS. Plantas de pessegueiro 'Maciel', em 2012, foram pulverizadas com quatro doses de ácido giberélico: 0; 25; 75 e $125 \mathrm{mg} \mathrm{L}^{-1}$, em três épocas: 20; 40 e 60 dias após a plena floração (DAPF). O número de gemas floríferas e, consequentemente, o número de flores foram reduzidos na safra de 2013. Houve redução do tempo de raleio manual mais acentuado nas doses aplicadas aos 60 DAPF. As doses de 25; 75 e $125 \mathrm{mg} \mathrm{L}^{-1}$ aplicadas aos 60 DAPF acarretaram em redução de 50,$1 ; 76,9$ e $87,1 \%$, respectivamente, no tempo de raleio manual. Nas condições do sul do Rio Grande do Sul, a dose de $25 \mathrm{mg} \mathrm{L}^{-1}$ de ácido giberélico aplicada aos 60 DAPF reduz o número de gemas floríferas e o tempo de raleio manual no ciclo subsequente, em pessegueiro 'Maciel', sem comprometer a produção. Termos para indexação: Pêssego, giberelinas, retorno da floração, inibição de flores, mão de obra, frutíferas de caroço.
\end{abstract}

\footnotetext{
'(Trabalho 013-15). Recebido em : 09-01-2015. Aceito para publicação em: 30-11-2015.

${ }^{2}$ Engenheiros Agrônomos, pós-graduandos em Agronomia, Fruticultura de Clima Temperado, Departamento de 27 Fitotecnia, Universidade Federal de Pelotas, Caixa Postal 354, CEP 96010-900, Pelotas, Rio Grande do Sul, Brasil. E-mails: giovanazmarcos@gmail. com; spagnol.agro@hotmail.com; dieweb@gmail.com, brunocarra@hotmail.com.

${ }^{3}$ Engenheiro Agrônomo, Doutor, Professor Titular, Departamento de Fitotecnia, Universidade Federal de Pelotas, 30 Caixa Postal 354 , CEP 96010-900, Pelotas, Rio Grande do Sul, Brasil. E-mail: jfachi@ufpel.tche.br.
} 


\section{INTRODUCTION}

The large amount of flowers and the high effective peach fruit set (NAVA et al., 2009) result in a load that the plant cannot stand, bearing fruit with low commercial value. In this regard, the thinning of fruit or flowers aims to reduce the plant load, increasing the size and quality of fruits, avoiding the production alternation and maximizing the final value of the product (BYERS et al., 2003; MEITEI et al., 2013). In the peach tree, thinning is usually performed in a manual way and is a delicate operation that requires high demand of manpower, short period for realization and high cost (COSTA; VIZZOTTO, 2000). Thinning in the peach tree represents a third of manpower total cost of the culture (LICHOU et al., 1997), and the practice may take 100 to $150 \mathrm{~h}$ $\mathrm{ha}^{-1}$, depending on the vigor of the plant, age, size, flower production and cultivar (TAHERI et al., 2012).

Aiming to replace or reduce the time of hand thinning, alternative studies with chemical thinning are being developed due to the high cost and uncertainty of future availability of manpower in the fruit production system worldwide (MCARTNEY et al., 2012).

A strategy that can be used to help the realization of thinning is the application of gibberellins in the flowering induction period, since it reduces the number of flowering buds of the subsequent cycle on stone fruit trees (SOUTHWICK; GLOZER, 2000; GRENNE; COSTA, 2013). Gibberellins are substances widely distributed in plants with different physiological functions, participating from seed germination, stem growth, until the transition to flowering and floral and fruitful development (TAIZ; ZEIGER, 2013). The results in reducing the number of flowers by applying gibberellins have been demonstrated for many years (HULL; LEWIS, 1959), and the exogenous application of gibberellic acid $\left(\mathrm{GA}_{3}\right)$ continues to be studied in recent decades, in peach trees, nectarine and plum trees (SOUTHWICK et al., 1995; GARCÍA-PALLAS et al., 2001; STERN; BEN-AIRE, 2009).

Coneva and Cline (2006), besides pointing out the advantage of gibberellic acid to be synthesized naturally by plants and have low environmental risks, also noted an improvement in fruit quality of 'Redhaven' peach after applying $\mathrm{GA}_{3}$ and suggested wide application opening in order to increase the fruit size and reduce thinning costs. In nectarine and peach trees, González-Rossi et al. (2007) also observed reduction in blossom after the application of $\mathrm{GA}_{3}$, resulting in the reduction of manual thinning time without interfering in production.
The results reported so far in the literature are from experiments carried out in specific climatic conditions in different regions, resulting in variations in doses recommendations and application times. In this regard, this study aimed to evaluate the reduction of flowering buds and hand thinning time in peach trees 'Maciel', after applying $\mathrm{GA}_{3}$ at different times and concentrations, in the subtropical conditions in southern Brazil, to reduce the number of flowers without changing in the production.

\section{MATERIAL AND METHODS}

The experiments were conducted in 2012 and 2013 crops, in a commercial orchard of peach trees located in the city of Morro Redondo-RS, Brazil (31 39 '55,09' $\mathrm{S}$ and 52 $34^{\prime} 51,30^{\prime}$ 'W). Plants from cultivar Maciel, 13 years old, grafted on rootstock 'Capdeboscq' were used. The plants were conducted in a potted system in an orchard which presents a planting density of 833 plants ha $^{-1}$, and spacing of 6 $\mathrm{m}$ between rows and $2 \mathrm{~m}$ between plants.

In 2012, the plants were sprayed with four doses of gibberellic acid: $0 ; 25 ; 75$ and $125 \mathrm{mg} \mathrm{L}^{-1}$ at three different times: 20; 40 and 60 days after full bloom (DAFB), which took place on 08/02/2012. The applications of different dosages were carried out by spraying, using backpack spraying equipment with an average spray volume of $1,000 \mathrm{~L} \mathrm{ha}^{-1}$. As a source of gibberellic acid, it was used the commercial product Pro-Gibb ${ }^{\circledR}$ containing $10 \% \mathrm{GA}_{3}$, being added in all treatments Assist ${ }^{\circledR}$ mineral oil at $0.2 \%$; and before application, adjusted the $\mathrm{pH}$ of the spray to five. The manual thinning was carried out at 55 DAFB, and before the harvest, counting of fruit number per plant was performed and 40 fruits per repetition was randomly picked to average fruit weight assessments $(\mathrm{g})$, yield per plant $(\mathrm{kg})$, average fruit diameter (mm) and soluble solids ( ${ }^{\circ}$ Brix), through a digital refractometer.

In 2013, six mixed shoots were selected by plant with size between 30 and $60 \mathrm{~cm}$, which were divided into three parts: basal, median and apical. The shoots were measured, and the count of flowering buds and flowers were made. The manual thinning was performed by a person, at $50 \mathrm{DAFB}$, leaving 10 to $15 \mathrm{~cm}$ from the fruit, being determined the necessary time for carrying out the practice. When the reduction of the number of flowers was higher, thinning was performed in a lighter way, just in order not to leave fruits in contact. Before harvest, the counting of the number of fruits per plant was conducted, being 40 fruits picked randomly by repetition, for assessments 
of production and fruit quality. It was determined the average fruit weight $(\mathrm{g})$ and calculated the yield per plant $\left(\mathrm{kg} \mathrm{plant}^{-1}\right)$. Through the use of measuring tape, it was made the reading of the fruit diameter and determined the mean diameter ( $\mathrm{mm}$ ). For evaluation of soluble solids, it was used digital refractometer and expressed in ${ }^{\circ}$ Brix.

The experimental design was randomized block in factorial $3\left(25,75\right.$ and $125 \mathrm{mg} \mathrm{L}^{-1}$ of $\left.\mathrm{GA}_{3}\right)$ x 3 (20, 40 and 60 DAFB) with additional control without the application of $\mathrm{GA}_{3}$. We used three replicates of four plants per plot, evaluating the two central plants. The results were submitted to analysis of variance $(p \leq 0.05)$, and the witness repeated in the time factor for the analysis of interaction between factors, and subsequently polynomial regression analysis was performed using the statistic program SPSS Statistics 20.

\section{RESULTS AND DISCUSSION}

The $\mathrm{GA}_{3}$ application in the 2012 cycle does not cause changes in the average mass and the mean diameter of the fruit, resulting in the same yield per plant in all treatments, with no changes in soluble solids (Table 1). According to Pegoraro et al. (2011), the application of $50 \mathrm{mg} \mathrm{L}^{-1}$ of $\mathrm{GA}_{3}$ at 45 DAFB in 'Chiripá' peach, provided the development of larger fruits, without changes in soluble solids, in the same year of application. However, Coneva and Cline (2006) found no changes in the average fruit weight of 'Redhaven' peach after $\mathrm{GA}_{3}$ application in four doses and in three different times. The Literature does not make clear the motive of the results variation in relation to the mass increment and fruit diameter of peach tree, after applying $\mathrm{GA}_{3}$. Because they are growth promoters and cell elongation plant hormones (JACKSON, 2003), treatment with gibberellins can result in increased size cells and, consequently, of the fruits (CURRY, 2012). However, the response may be related to genetic factors and the levels of endogenous gibberellins intrinsic of each cultivar.

The number of flowering buds and, consequently, of flowers was reduced in the 2013 harvest after the application of gibberellic acid at 2012 harvest. It can be seen in Figure 1A and 1B, which there was no statistical interaction among the $\mathrm{GA}_{3}$ doses used and the product application times. In Figure 1A, the doses applied at 20; 40 and 60 DAFB had a negative quadratic curve, with reduction of flowering buds similar to the applications at 20 and 40 DAFB. The application at 60 DAFB caused the greatest reduction in the number of flowering buds when compared to the other treatments, regardless of the dose used. The doses of 25; 75 and $125 \mathrm{mg}$ $\mathrm{L}^{-1}$ applied at 60 DAFB resulted in reduction of $32.2 ; 48.1$ and $71.6 \%$, respectively, in the number of flowering buds compared to the control-treatment.

In Figure 2, it can be seen reduction of manual thinning time stronger in doses applied at 60 DAFB. The doses of 25; 75 and $125 \mathrm{mg} \mathrm{L}^{-1}$ applied at 60 DAFB resulted in reduction of $50.1 ; 76.9$ and $87.1 \%$ respectively in manual thinning time compared to the control treatment. The dose of $125 \mathrm{mg} \mathrm{L}^{-1}$ applied at 40 DAFB reduced by $44.6 \%$ the time to perform the manual thinning, which was lower than the lowest dose $\left(25 \mathrm{mg} \mathrm{L}^{-1}\right)$ applied at $60 \mathrm{DAFB}$, highlighting the greater reliance on the application time than the $\mathrm{AG}_{3}$ doses used. The dose with higher efficiency in reducing manual thinning time was of $87.29 \mathrm{mg}$ $\mathrm{L}^{-1}$ applied at $60 \mathrm{DAFB}$, which would result in a reduction of $87.3 \%$ in the manual thinning time when compared to the control.

Studies reported by literature showed reduction in the number of flowering buds and flowers in the following harvest after applying $\mathrm{GA}_{3}$; however, there is some variation of the biggest effect among doses and the applied times. In studies performed in the climatic conditions of Israel (subtropical), Stern and Ben-Aire (2009) concluded that a dose of 25 $\mathrm{mg} \mathrm{L}^{-1}$ applied at 60 DAFB was sufficient to reduce the number of flowers per plant, and consequently manual thinning without interfering with productivity per plant. In experiments in Spain, González-Rossia et al. (2007), when applying $75 \mathrm{mg} \mathrm{L}^{-1}$ of $\mathrm{GA}_{3}$ at 101 DAFB, observed reduction of manual thinning time without affecting the final yield of 'Springlady' peach trees. In Canada, Coneva and Cline (2006) suggest wide application opening of $\mathrm{AG}_{3}$, from 7 to 13 weeks after the full bloom, and the doses used may vary from 50 to $150 \mathrm{mg} \mathrm{L}^{-1}$.

Although Southwick and Glozer (2000) report that several factors, such as weather, light, nutrition, rootstock and pruning interfere in the shoot growth and at the time of floral initiation throughout the season, the same authors, in their experiments by several years, found consistency in the results in their region. They point out that small changes should be made between cultivars and that the spring temperatures must be observed, as conditions of low temperatures can slow the growth of the shoots, which would delay the application of $\mathrm{GA}_{3}$ (SOUTHWICK; FRITTS, 1995; SOUTHWICK et al ., 1995; SOUTHWICK et al, 1998;. SOUTHWICK; GLOZER, 2000).

At the time of flower buds counting, it was observed desuniformity inhibition of buds along the shoot. It can be seen in Figure 3 that while the control treatment exhibit fewer bud flowers in the 
basal part, the inhibitory effect of $\mathrm{GA}_{3}$ is superior in buds located in the basal segment of the shoot and this inhibition is also dependent on the application time performed. The dose of $125 \mathrm{mg} \mathrm{L}^{-1}$ applied at 60 DAFB was the one that showed the highest inhibitory effect; reduced to zero the number of flowers buds in the basal segment of the shoots presented fewer gems in the middle segment and was similar to the other treatments in the apical segment.

The applications of $\mathrm{GA}_{3}$ in peach by González-Rossia et al. (2007) and Stern and BenAire (2009) also resulted in higher inhibition of basal buds, causing desuniformity in the inhibition of the flowering buds. The floral initiation period varies along the peach tree shoot, which occurs later in the apical segment of the shoot (SOUTHWICK; GLOZER, 2000). González-Rossia et al. (2007) suggest that the persistence of gibberellic acid on the outer surface is limited; thus $\mathrm{AG}_{3}$ action is reduced in buds that will develop later, which explains the larger number of flowers buds in the apical part of the branches. In this regard, winter pruning must be planned so that does not occur the lopping of the shoots which would result in excessive reduction of flowers. It is suggested that future experiments should be planned with the division of the dose over time, coinciding with the application of the product with different stages of shoot growth and floral induction of vegetative primordia, which might result in a more uniform inhibition along the shoot.

The number of fruits per plant at harvest significantly reduced in the doses applied at 60 DAFB (Table 2). Due to the high reduction of the number of buds and the mild thinning performed to the removal of very close fruits, the plant load was reduced which compromised the productivity for the dosages of 75 and $125 \mathrm{mg} \mathrm{L}^{-1}$ (Figure 2B). However, it is noticed considerable increase in mean weight and average fruit diameter, due to lower initial competition for carbohydrates among fruits and the increase in the source / drain ratio of the plant (BYERS et al., 2003).

The gibberellins mechanism of action on the inhibition of flowering buds is not yet understood. It has been suggested that the seeds are rich sources of these gibberellins and are exported to the buds. However, it was not possible to find convincing evidence that the exported amount of gibberellins is enough and it was proposed that the auxin is a mobile inhibitor. The application of gibberellin can inhibit the floral initiation by increasing the polar transport of indolylacetic acid (IAA) from the seeds, and alternatively, if gibberellins really are floral inhibitors, IAA can stimulate its synthesis in the buds (MUTASA-GÖTTGENS; HEDDEN, 2009).
The reduction of the number of flowering buds in peach trees by the application of $\mathrm{GA}_{3}$ can be combined with other existing techniques of chemical thinning because there is promising results with chemical thinning of flowers reported in the literature in the recent years. The use of ammonium thiosulfate (GREENE et al., 2001; YOON et al, 2011) and surfactants (SOUTHWICK et al., 1996; FALLAHI et al., 2006) resulted in a reduction of the plants load and in the increasing of fruit size. According to Costa and Vizzotto (2000), it is difficult to find a strategy to avoid the manual transfer in peach trees, suggesting the use of substances in successive phenological stages, strategy adopted successfully in apple trees.

A reduction in the number of flowering buds by applying $\mathrm{GA}_{3}$ presents damage risks from late frosts. However, we should consider the high cost presented by manual thinning and the unavailability of this manpower in peach-producing regions. The use of this growth regulator should consider the flowering earliness, the cultivar fertilization and the value of the crop after subtracting the cost of manpower and their availability. 
TABLE 1 - Effect of $\mathrm{GA}_{3}$ application on the number of fruits per plant, weight and mean diameter of the fruits, production and soluble solids (SS) in 'Maciel' peach trees. Morro Redondo RS-2012.

\begin{tabular}{|c|c|c|c|c|c|c|}
\hline DAFB & $\begin{array}{c}\mathrm{GA}_{3} \\
\left(\mathrm{mg} \mathrm{L}^{-1}\right)\end{array}$ & Fruits plant ${ }^{-1}$ & $\begin{array}{c}\text { Mean } \\
\text { weight }(\mathrm{g})\end{array}$ & $\begin{array}{r}\text { Production } \\
\left(\text { kg plant }^{-1}\right)\end{array}$ & $\begin{array}{c}\text { Mean } \\
\text { diameter } \\
(\mathrm{mm})\end{array}$ & $\begin{array}{c}\mathrm{SS} \\
\left({ }^{\circ} \mathrm{Brix}\right)\end{array}$ \\
\hline \multirow{4}{*}{20} & 0 & 290 & 127 & 36.7 & 60.7 & 12.2 \\
\hline & 25 & 304 & 132 & 39.8 & 61.5 & 12.4 \\
\hline & 75 & 318 & 125 & 39.5 & 60.4 & 12.7 \\
\hline & 125 & 311 & 120 & 37.4 & 61.6 & 12.6 \\
\hline \multirow[t]{3}{*}{40} & 25 & 288 & 132 & 37.1 & 61.6 & 12.6 \\
\hline & 75 & 282 & 136 & 38.3 & 62.1 & 128 \\
\hline & 125 & 255 & 137 & 35.0 & 63.1 & 12.9 \\
\hline \multirow[t]{3}{*}{60} & 25 & 273 & 135 & 36.4 & 63.1 & 12.8 \\
\hline & 75 & 250 & 137 & 33.6 & 62.3 & 12.9 \\
\hline & 125 & 280 & 133 & 36.7 & 60.5 & 12.7 \\
\hline$P(\mathrm{DAFB})$ & & ns & ns & ns & ns & ns \\
\hline$P\left(\mathrm{GA}_{3}\right)$ & & ns & ns & ns & ns & ns \\
\hline$P\left(\right.$ DAFB $\left.\times \mathrm{GA}_{3}\right)$ & & ns & ns & ns & ns & ns \\
\hline
\end{tabular}

ns, not significant. DAFB, days after full bloom. GA, gibberellic acid.

TABLE 2- Effect of $\mathrm{GA}_{3}$ application on the number of fruits per plant, weight and mean diameter of the fruit and production of 'Maciel' peach tree. Morro Redondo-RS, 2013.

\begin{tabular}{|c|c|c|c|c|}
\hline DAFB & $\begin{array}{c}\mathrm{GA}_{3} \\
\left(\mathrm{mg} \mathrm{L}^{-1}\right)\end{array}$ & Fruits plant $^{-1}$ & $\begin{array}{c}\text { Mean } \\
\text { weight }(\mathrm{g})\end{array}$ & $\begin{array}{c}\text { Mean } \\
\text { diameter }(\mathrm{mm})\end{array}$ \\
\hline \multirow[t]{4}{*}{20} & 0 & 320 & 108 & 58 \\
\hline & 25 & 327 & 103 & 58 \\
\hline & 75 & 317 & 111 & 59 \\
\hline & 125 & 288 & 110 & 59 \\
\hline \multirow[t]{4}{*}{40} & 0 & 320 & 108 & 58 \\
\hline & 25 & 295 & 110 & 57 \\
\hline & 75 & 306 & 111 & 58 \\
\hline & 125 & 285 & 122 & 61 \\
\hline \multirow[t]{5}{*}{60} & 0 & 320 & 108 & 58 \\
\hline & 25 & 299 & 124 & 60 \\
\hline & 75 & 193 & 144 & 64 \\
\hline & 125 & 162 & 146 & 66 \\
\hline & $r^{2}$ & $0.84^{* *}$ & $0.66^{* *}$ & $0.87^{* * *}$ \\
\hline$P(\mathrm{DAFB})$ & & $* * *$ & $* * *$ & *** \\
\hline$P\left(\mathrm{GA}_{3}\right)$ & & *** & $* * *$ & $* * *$ \\
\hline$P(\mathrm{DAFB} x$ & & * & $* *$ & $*$ \\
\hline
\end{tabular}

*, ****** significant at $P<0.05 ; 0.01$ and 0.001 , respectively, after factorial analysis of variance and regression analysis to the factor DAFB. DAFB, days after full bloom. GA, gibberellic acid. 



FIGURE 1- Effect of application of gibberellic acid $\left(\mathrm{GA}_{3}\right)$ on flowering of 'Maciel' peach tree. A) number of flowers buds in 2013; and B) flowering return. Morro Redondo-RS, 2013. DAFB, days after full bloom.

*,*****, significant at $P<0.05 ; 0.01$ and 0.001 , respectively, after analysis of variance. 

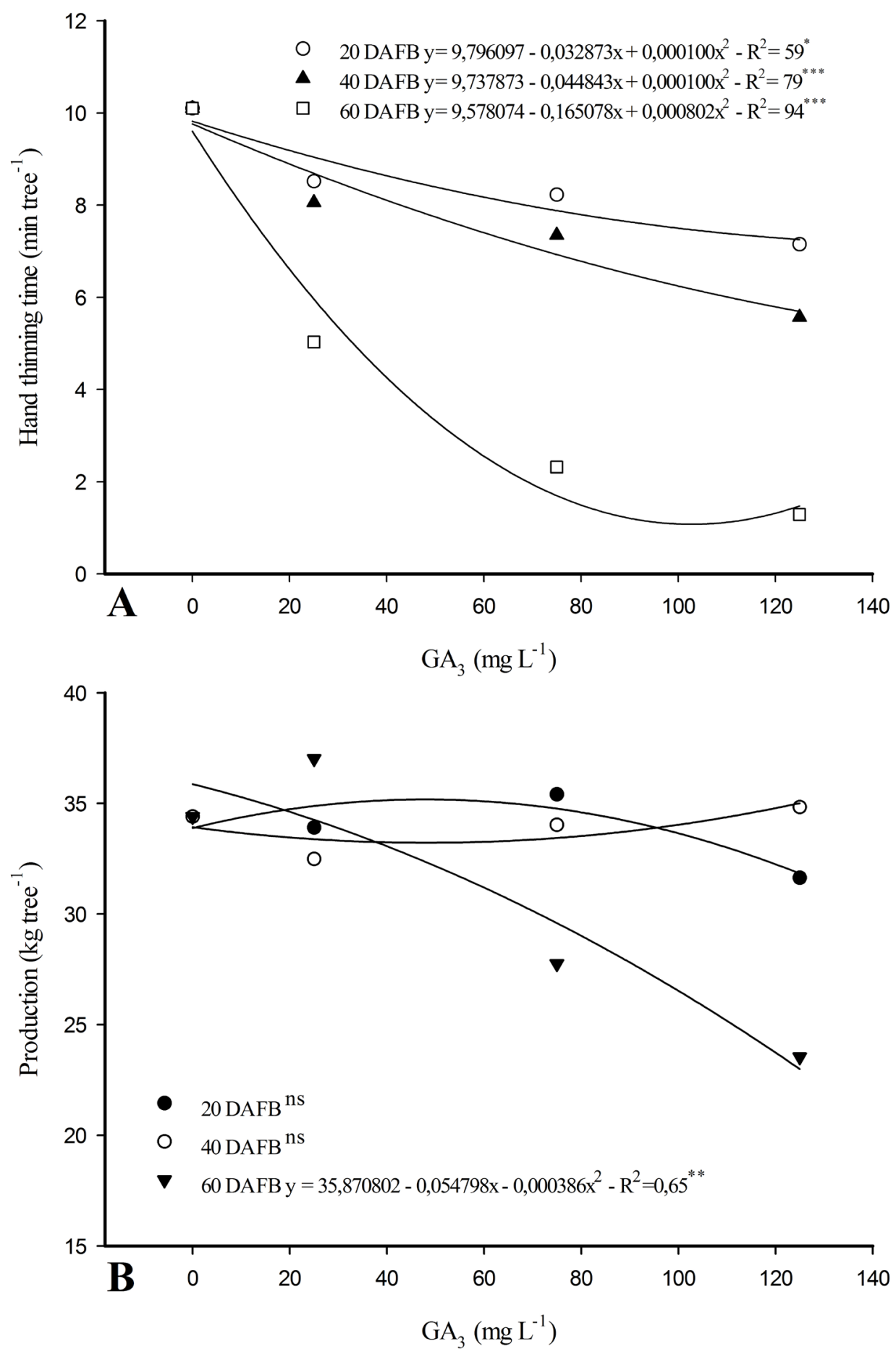

FIGURE 2- Effect of application of gibberellic acid $\left(\mathrm{GA}_{3}\right)$ on the time required to perform the manual thinning (A) and production in 'Maciel' peach trees (B). Morro Redondo-RS, 2013. DAFB, days after full bloom.

ns, ${ }^{*},{ }^{* *},{ }^{* * *}$, not significant and significant at $P<0.05 ; 0.01$ and 0.001 , respectively, after analysis of variance. 


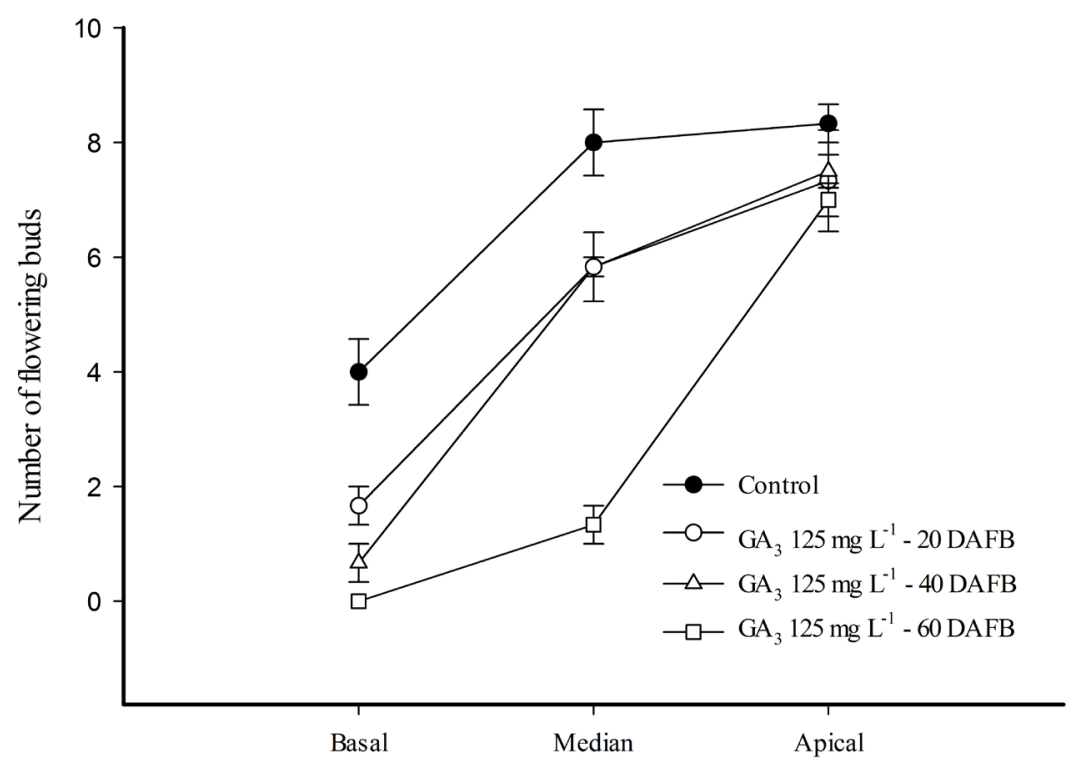

FIGURE 3- Effect of time of application of gibberellic acid $\left(\mathrm{GA}_{3}\right)$ on the uniformity of flowering buds inhibition along the shoot of 'Maciel' peach trees. Morro Redondo-RS, 2013. DAFB, days after full bloom. Vertical bars represent the mean standard error $(n=3)$.

\section{CONCLUSIONS}

The dose of $25 \mathrm{mg} \mathrm{L}^{-1}$ of gibberellic acid applied at 60 DAFB reduce the number of flowering buds and manual thinning time in the subsequent cycle of 'Maciel' peach trees, without compromising the production.

The dose of $87.29 \mathrm{mg} \mathrm{L}^{-1}$ of gibberellic acid causes the greatest reduction in manual thinning time $(87.3 \%)$; however, reduces the production per plant.

The application of gibberellic acid reduces unevenly the number of flowers buds along the shoot in 'Maciel peach trees.

\section{ACKNOWLEDGMENT}

To the Conselho Nacional de Desenvolvimento Científico e Tecnológico (CNPq), and to the Coordenação de Aperfeiçoamento de Pessoal de Nível Superior (Capes), for financial support. The farmer Mr. Flávio Gilberto Herter to make available the property for the experiment.

\section{REFERÊNCIAS}

BYERS, R.E.; COSTA, G.; VIZZOTTO, G. Flower and fruit thinning of Peach and other Prunus. Horticultural Reviews, New York, v.28, p.351392, 2003.

CONEVA, E.D.; CLINE, J. Blossom thinners reduce crop load and increase fruit size and quality of peaches. HortScience, St Joseph, v.41, p.15961601, 2006.

COSTA, G.; VIZZOTTO, G. Fruit thinning of peach trees. Plant Growth Regulation, Netherlands, v.31, p. 113-119, 2000.

CURRY, E. Increase in Epidermal Planar Cell Density Accompanies Decreased Russeting of 'Golden Delicious' Apples Treated with Gibberellin $\mathrm{A}_{4+7}$. Hortscience, St Joseph, v.47, p.232-237, 2012.

FALLAHI, E.; FALLAHI, B.; MCFERSON, J.R.; BYERS, R.E.; EBEL, R.C.; BOOZER, R.T.; PITTS, J.; WILKINS, B.S. Tergitol-TMN-6 surfactant is an effective blossom thinner for stone fruits. HortScience, St Joseph, v.41, p.1243-1248, 2006. 
GARCÍA-PALLAS, I.; VAL, J.; BLANCO, A. The inhibition of flower bud differentiation in 'Crimson Gold' nectarine with $\mathrm{GA}_{3}$ as an alternative to hand thinning. Scientia Horticulturae, Amsterdam, v.90, p.265-278, 2001 .

GONZÁLES-ROSSIA, D.; REIG, C.; JUAN, M.; AGUSTÍ, M. Horticultural factors regulation effectiveness of GA3 inhibiting flowering in peaches and nectarines (Prunnus persica L. Batsch). Scientia Horticulturae, Amsterdam, v.111, p.352-357, 2007.

GREENE, D.W.; HAUSCHILD, K.I.; KRUPA, J. Effect of blossom thinners on fruit set and fruit size of peaches. HortTechnology, The Hague, v.11, p.179-183, 2001.

GREENE, D.W.; COSTA, G. Fruit Thinning in Pome- and Stone-Fruit: State of the Art. Acta Horticulturae, The Hague, v.998, p.93-102, 2013.

HULL, J.; Jr.; LEWIS, L.N. Response of oneyear-old cherry and mature bearing cherry, peach and apple trees to gibberellin. Proceedings of the American Society Horticultural Science, Genova, v.74, p.93-100, 1959

JACKSON, J. Biology of apples and pears. Cambridge: Cambridge University Press, 2003. 488 p.

LICHOU, J.; JAY, M.; GONSOLIN, L.; MASSACRIER, M.L.; DU FRETAY, G. Armothin ${ }^{\circledR}$ : a new chemical agent efficient for peach blossom thinning. Acta Horticulturae, The Hague, v.451, p.683-692, 1997.

MCARTNEY, S.J.; OBERMILLER, J.D.; ARELLANO, C. Comparison of the effects of metamitron on chlorophyll fluorescence and fruit set in apple and peach. HortScience, St Joseph, v.47, p.509-514, 2012.

MEITEI, S.B.; PATEL, R.K.; DEKA, B.C.; DESHMUKH, N.A.; SINGH, A. Effect of chemical thinning on yield and quality of peach cv. Flordasun. African Journal of Agricultural Research, Nairobe, v.8, p.3358-3565, 2013.

MUTASA-GÖTtGENS, E.; HEDDEN, P. Gebberellin as a factor in floral regulatory networks. Journal of Experimental Botany, Lancaster, v.60, p.1979-1989, 2009.

NAVA, G.A.; MARODIN, G.A.B.; SANTOS, R.P. Reprodução do pessegueiro: efeito genético e de manejo das plantas. Revista Brasileira de Fruticultura, Jaboticabal, v.31, p.1218-1233, 2009.
PEGORARO, C.; CHAVES, F.C.; CERO, J.D.; GIRARDI, C.L. ROMBALDI, C.V. Effects of preharvest gibberellic acid spraying on gene transcript accumulation during peach fruit development. Plant Growth Regulation, Netherlands, v.65, n.2, p.231237, 2011.

SOUTHWICK, S. M.; FRITTS, R. Commercial chemical thinning of stone fruit in California by gibberellins to reduce flowering. Acta Horticulturae, The Hague, v.394, p.135-147, 1995.

SOUTHWICK, S.M.; WEIS, K.G.; YEAGER, J.T.; ZHOU, H. Controlling cropping in 'Loadel' cling peach using gibberellin: Effects on flower density, fruit distribution, fruit firmness, fruit thinning and yield. Journal of the American Society for Horticultural Science, Alexandria, v.120, p.10871095, 1995.

SOUTHWICK, S. M.; WEIS, K.G.; YEAGER, J.T. Bloom thinning 'Loadel' cling peach with a surfactant. Journal of the American Society for Horticultural Science, Alexandria, v.121, p.334338, 1996.

SOUTHWICK, S. M.; WEIS, K.G.; HASEY, J.K. Chemical thinning of cling peach. Acta Horticulturae, The Hague, v.465, p.647-653, 1998.

SOUTHWICK, S.M.; GLOZER, K. Reducing flowering with gibberellins to increase fruit size in Stone fruit trees: aplications and implications in fuit production. HortTechnology, Alexandria, v.10, p.744-751, 2000.

STERN, R.A.; BEN-ARIE, R. GA3 inhibits flowering, reduces hand-thinning, and increases fruit size in peach and nectarine. The Journal of Horticultural Science e Biotechnology, Ashford, v.84, p. 119-124, 2009.

TAHERI, A.; CLINE, J.A.; JAYASANKAR, S.; PAULS, P.K. Ethephon-inuduced abscission of "Redhaven" peach. American Journal of Plant Sciences, Irvine, v.3, p.295-301, 2012.

TAIZ, L.; ZEIGER, E. Fisiologia vegetal. 5.ed. Porto Alegre: Artmed, 2013; 918p.

YOON, T.M.; OSBORNE, J.L.; ROBINSON, T.L. Blossom thinning of 'Redhaven' and 'Babygold 5' peaches with different chemicals. Acta Horticulturae, The Hague, v.903, p.833-840, 2011. 